\title{
BEST PRACTICES TO IMPROVE THE HEALTHCARE PATIENT EXPERIENCE IN GYNAECOLOGY AND OBSTETRICS
}

\section{LENKA EMROVÁ}

\begin{abstract}
:
The quality and level of the Czech healthcare system is a very current and often discussed topic. The Czech healthcare system is considered to be one of the most advanced healthcare systems in the world, but is very often criticized as being too "technological" and "scientific" and the psychosocial aspects are neglected. The social competencies of doctors are expected, but not enough attention is payed to their definition, development and creation of conditions for their application. We need to change the curriculum for undergraduate and postgraduate doctors' psychosocial preparation. The research focuses on gynaecological and obstetric specialization, where the need for a psychosocial approach is seen as being essential. This paper reviews the conceptual and empirical literature in order to develop a model of the various aspects of the doctor-patient relationship encompassed by the "patient-centred" concept. Based on the empirical studies we identified "best practices" that should be essential for education based on the competency for undergraduate and postgraduate doctors' preparation. The main methods are three focus groups for six doctors at different levels of experience and nine in-depth interviews with expectant mothers who had varying experiences with parturition: spontaneous parturition, planned caesarean section parturition, long-term hospitalization up to four weeks. The main outcome of the study is to describe the best practise of doctors/obstetricians, which is acceptable to doctors and corresponds to the needs and expectations of mothers.
\end{abstract}

\section{Keywords:}

Quality of healthcare; Patient-centred care; Competence, Social competence, Doctor-patient relations; Competency Models in Health Care; Communication; Medical education-based competency, Gynaecology; Obstetrics.

JEL Classification: D74, 123, A14

\section{Authors:}

LENKA EMROVÁ, Department of Psychology, Faculty of Arts, Charles University, Czech Republic, Email: lenka.emrova@seznam.cz

\section{Citation:}

LENKA EMROVÁ (2020). Best Practices to Improve the Healthcare Patient Experience in Gynaecology and Obstetrics. International Journal of Social Sciences, Vol. IX(1), pp. 22-43.,

10.20472/SS.2020.9.1.002 


\section{Introduction}

Recently, we have seen incredible scientific and technological advances in the healthcare system in gynaecology and obstetrics. The Czech healthcare system is considered one of the best in the world. Despite that, numerous research studies in this area confirm that patients are not satisfied with the relationship between doctors and patients (Takács et al., 2012; Takács \& Seidlerová, 2013, Takács, 2016). T. Gordon (1995) cites many studies (C.E. Kopp, 1992, Remen, 1975, Spencer, 1990) that point to the fact that the healthcare system is too "technology and science oriented, problem focused, disease-centred or doctor-centred". Doctors should be more "humanistic oriented, person focused and patient centred". He also lists a large number of benefits that effective communication can bring, e.g. more patients' trust, higher patients' compliance, greater patients' satisfaction, less resistance to treatment, greater patients' selfesteem and independence in treatment. A growing body of evidence shows that people who are actively involved in protecting their health and managing their healthcare have better health outcomes (Coulter \& Ellins 2006).

There are several factors that put pressure on changing the existing biomedical system, which has been a model of the past few centuries and still persists. Firstly, increasing patients' diversity and a wider portfolio of needs and expectations that enforce an individual approach. Also increasing rates of chronic disease. Secondly, doctors' offices and hospitals are increasingly considered as service providers, and patients perceive themselves as clients. Thirdly, patients' needs and expectations change as a result sociocultural changes, the increasing knowledge and empowerment of patients and a heightened awareness of their possibilities leads to patients want to be more informed, they have more assertive and active approach and they want to become more involved and participate in the treatment process. Finally, there is a growing interest in emotions and emotional aspects of care supported advances in medical science. The healthcare system will need to adapt to support these changes, and hospitals and healthcare systems will need to acquire new competencies.

It has always been expected that doctors should be trustworthy and act in the interest of their patients (Hasman et al 2006). As Violato et al (2003) observes, thinking in the Western world about medical competence has shifted. Interpersonal skills and competence in patient engagement have come to the foreground. It is recognized that communication skills, interpersonal skills and professionalism sit alongside clinical decision-making and medical expertise as components of competence (Frank 2005, ACGME 2001, Levine 2002, Epstein \& Hundert 2002, Maudsley et al 2000, Hall et al 1999, Violato et al 1997). Furthermore, patients nowadays also expect doctors to respect their autonomy, to listen to them, to inform them, to take 
account of their preferences, to involve them in treatment decisions and to support their efforts in self-care (Coulter \& Magee 2003).

We are convinced that there are more psychosomatic disease and psychosocial issues in gynaecology and obstetrics, so it is necessary to further support and develop the psychosocial competences of doctors in this specialization. We will mention some of the areas: the birth experience is a "critical period" in a woman's life that is accompanied by increased sensitivity and vulnerability, and it has significant (and long-term) impacts on her physical and mental health, her relationship with the child, her sense of parenting competence and thus further development (DiMatteo et al., 1996; Bailham \& Joseph, 2003; Michels, Kruske, \& Thompson 2013). A relationship and good communication between a doctor and a mother is an assumption for establishing a trustworthy relation and cooperation. Good cooperation reduces anxiety and stress and contributes to a more positive experience of birth and postpartum periods and to greater satisfaction of the mothers. (Takács, Sobotková, \& Šulová, 2015). There are other individual areas, where is psychosocial approach necessary e.g. women, who suffer childbirth anxiety and this prevents them from becoming pregnant or their competences to give birth, some women experience the delivery of a child as so traumatic that they develop posttraumatic stress disorder (PTSD). Since the late 1990s, scientific articles have been published related to childbirth as a potential traumatic event. Because of the possible implications for mother, infant, and family, it is important that obstetric care professionals and those providing care in the first postnatal year in community settings recognize and acknowledge PTSD following childbirth and that they are aware of possible risk factors, consequences, and treatment options. Another very complicated issue is the introduction of non-invasive prenatal testing (NIPT) on to the market. The existence of prenatal tests allows, and at the same time forces, pregnant women to make decisions and choices. Ethically delicate questions arise such as the value of unborn life, the value of a life of a child with a mental handicap, and the consideration about pros and cons regarding the impact on the parents' life. The decision whether to terminate a pregnancy or not is very much dependent on the individual evaluation of the couples and they need sensitive and at the same time professional guidance without manipulation. Another issue "perinatal loss" refers to the psychosocial consequences of a pregnancy or birth ending in the death of the foetus or new-born. This loss is a devastating experience for parents, families, and, often, healthcare staff as well. Therefore, this situation requires a great deal of knowledge of the psychosocial approach. Clinical management of perinatal loss has changed in the last decades in most Western countries, especially in those with adequate healthcare standards and in those where psychosocial issues are normally included in standard perinatal care (Lewis E, Page A., 1978; Cain AC, Cain BS., 
1964; Green M, Solnit AJ., 1964; Posnaski EO, 1972; Klaus M, Kennel J.,1982; Bourne S, Lewis E., 1992). From the 1980s onwards, more and more attention was paid to the deleterious effects of perinatal loss, especially when followed by inadequate healthcare management. Appleby, for instance, showed an increase of $600 \%$ in suicide rates after perinatal loss (Appleby L., 1991), and Condon pointed out a significant increase in psychiatric hospitalization and consequences for children born after the loss (Condon J., 2010). Women with Premenstrual Syndrome. Premenstrual disorders are a combination of emotional, behavioural, and/or physical symptoms that are present in the days prior to menses and resolve shortly after menses. The severity of the symptoms causes clinically significant distress and interferes with relationships and role functioning. A couple, who cannot conceive: infertility. Because the period in which a couple is suffering from infertility encompasses many stressful moments and events, it is difficult, if not impossible, to determine exactly "what causes what." According to the literature, successful coping in this situation of infertility is mainly influenced by the history of the desire for a child, the medical diagnosis, the patients' estimations of treatment success, and the actual strategies of both partners of the couple.

\section{$1.1 \quad$ Patient-Centred Care}

In the past 30 years, an extensive body of literature has emerged advocating a "patient-centred" approach to medical care. Yet despite the popularity of the concept there is little consensus as to its meaning. Edith Balint (1969) describes patient-centred medicine as, "Understanding the patient as a unique human being", while for Byrne and Long (1976) it represents a style of consulting where the doctor uses the patient's knowledge and experience to guide the interaction. McWhinney (1989) describes the patient-centred approach as one where, "The physician tries to enter the patient's world, to see the illness through the patient's eyes"'. Giving information to patients and involving them in decision-making have also been highlighted (e.g. Lipkin, Quill\& Napodano, 1984; Grol, de Maeseneer, Whitfeld \&Mokkink, 1990; Winefield, Murrell, Clifford \& Farmer, 1996). For Laine and Davidoff (1996), patient-centred care is, "Closely congruent with, and responsive to patients' wants, needs and preferences". The most comprehensive description is provided by Stewart, Brown, Weston, McWhinney, McWilliam and Freeman (1995a) whose model of the patient-centred clinical method identifies six interconnecting components: 1. Exploring both the disease and the illness experience, 2. Understanding the whole person, 3. Finding common ground regarding management, 4. Incorporating prevention and health promotion, 5. Enhancing the doctor-patient relationship, and 6. Being realistic about personal limitations and issues such as the availability of time and resources. According to Little et al. 
(2001, pp. 1-7), there are several elements to models of patient-centred approaches based on changed relationships and communication between health professionals and patient, focussing on exploring, understanding, finding and enhancing (p. 1) Their research concluded that for patients, the key components were communication, partnership, and health promotion (p. 5). Stewart et al. (2003) work on patient-centred medicine is an example of PCC being put into practice in a clinical setting and provides insight into how PCC is understood. Their patient-centred clinical method is made up of six interactive components including validating the patient's experiences, considering the broader context in which the illness is experienced, working towards mutual understandings between doctor and patient, engaging in health promotion, taking a partnership approach to the doctor-patient relationship and being realistic about goals. (Stewart et al., 2003).

In 2000, Mead and Bower identified five conceptual dimensions of patient-centred care, distinguishing this approach from the conventional biomedical model (Mead, Bower, 2000, p.1087 - 1091): Biopsychosocial perspective; Patient as a person; Sharing power and responsibility; The therapeutic alliance; The doctor-as-a-person.

Eklun, J.H., Holmstrom, I.K., Kumlin, T. et al. (2017, pp. 6-8) examined distinguishes between person-centred and patient-centred care and the analysis result was nine themes present in person-centred as well as in patient-centred care: 1. Empathy, 2. Respect, 3 Engagement, 4. Relationship, 5. Communication, 6. Shared decision-making, 7. Holistic focus, 8. Individualized focus, and 9. Coordinated care.

\subsection{The Competency models}

In 2002, the Institute of Medicine organized an interdisciplinary summit to reform education in the healthcare professions with a view to improving the quality of care and patient safety. The result was "A Bridge to Quality", where a core set of competencies was integrated in health care. The committee defined professional competence as the habitual and judicious use of communication, knowledge, technical skills, clinical reasoning, emotions, values, and reflection in daily practice for the benefit of the individuals and community being served (Hundert et al., 1996). Competencybased education refers to educational programs designed to ensure that students achieve prespecified levels of competence in a given field or training activity. A core competency is the identified knowledge, ability, or expertise in a specific subject area or skill set that is shared across the health professions. In this report, competency denotes an individual doctor's actual 
performance in a specific job function or task, and competencies or competency areas are skills considered necessary to perform a specific job or service (Kelly-Thomas, 1998).

The core set of competencies integrated into health professions education were: to provide patient-centred care, to work in interdisciplinary teams, evidence-based practice, to apply quality improvement, and to utilize informatics.

There is currently no congruence in the understanding of this concept among experts in the field of competencies. The problem is the discrepancy in the expression of what the competence creates and what not. We can say that there are as many definitions of competence as there are researchers in the field. For the purposes of this paper, we will use the following pragmatic definition: "Competences consist of the repertoire of behaviour and actions a health professional can use to solve complex problems in a wide range of situations in a creative and effective way". This definition is closely linked to the seven characteristic properties attributed to competences by Veteška, Tureckiová (2008):

1. Competences are context-dependent:

2. Competences are indivisible

3. Competences are changeable.

4. Competences are learnable.

5. Competences are manifested in behaviour that is visible and can therefore also be tested.

6. Competences are related to each other. The acquisition of a competence requires the presence of other competences.

7. Determined by standard. The expected level of competence is determined in advance. This allows competence to be measured and evaluated.

(modified and supplemented according to Veteška, Tureckiová, 2008, pp. 31 - 32).

Social competence has been viewed as a multifaceted construct involving social assertion, frequency of interaction, positive self-concept, social cognitive skills, popularity with peers, and the list goes on and on (Dodge, 1985). If we were to find full-area definition of social competence, we would use Smékal's definition (2007), who describes this competence as the "proficiency, qualification, man's mastery to deal with people efficiently and solve problems of incorporation oneself into a group and activity within this group in compliance with company's aims and following the moral principles. Everybody who lives and cooperates with people must possess the social competence. Social competences is the structure of habits, needs, attitudes and etc. Its 
core is self-reflection which is the essential for the proper behaviour towards people that the person comes into contact with". (Smékal, 2007).

In the Western healthcare world professional roles that are relevant for all doctors are summarized in the competency models that determinate and describe their abilities and skills required to effectively meet the healthcare needs of the people they serve. Their relevance lies in the behavioural repertoire associated with the various roles. This behaviour can be used to deal with a variety of complex problems in a wide range of situations. The advantage of the clusters of knowledge, skills, and attitudes that go with this behaviour is that they are universal, they transcend specialties and disciplines. They are competences that can be applied in equal measure by other professionals such as midwives and even by HR staff, managers, and executives. A great advantage of thinking in terms of competences is that it offers a common frame of reference, a universal language to describe what a person needs to do and not do in order to become, to be, and to continue to be a good professional. The disadvantage is that the ideas and terminology that go with it soon tend to become abstract and incomprehensible. The Medical Council of Canada has defined them as the Canadian Medical Education Directives for Specialists (CanMEDS) roles, the General Medical Council (GMC) of the United Kingdom has published them in Good Medical Practice (GMP), and the Accreditation Council for Graduate Medical Education (ACGME) has identified its own set of competencies in the United States (Frank J.R., 2005; Palmer KT et al., 2002; Irvine D., 2001; Swing SR., 2007). Despite the fact that there is considerable similarity across them, each set is tailored to the specific needs of the country. They focused attention on the core competencies required of health care providers. The competency model could be an efficient tool which is designed to evaluate the doctor's qualification, and it will become a significant instrument for the medical education development or for recruitment and evaluation of health professionals in the future. Canada has a world-class reputation in medical education and also has been a leader for decades, since launching the seven essential CanMEDS roles of a doctor (communicator, collaborator, health advocate, leader, medical expert, professional, scholar). Many countries have implemented pioneering work from Canada. Good medical practice describes what is expected of all doctors registered with the General Medical Council (GMC). Patients must be able to trust doctors with their lives and health. To justify that trust doctors must show respect for human life and make sure their practice meets the standards expected of them in four domains: 1 . Knowledge, skills and performance, 2 . Safety and quality, 3. Communication, partnership and teamwork, and 4. Maintaining trust (GMP, 2013). ACGME in United States identified six competences: 1. Patient care, 2. Medical knowledge, 3. 
Interpersonal and communication skills, 4. Professionalism, 5. Practise-based learning and improvement, and 6. System-based practise.

There are no models in the Czech Republic. The research is motivated by the above-described situation of the Czech healthcare system and inspired by the above-mentioned research models of competences in Western countries. It will be necessary for the Czech Republic to develop a competency model that could serve as a basis for education in both undergraduate and postgraduate positions and at the same time for work within human resources in individual hospitals. It is necessary to change priorities within the framework of social competences, both at the level of education and at the level of organizational structure of hospitals and health care facilities. Therefore, we want to explore which best practices are core competences within the domain of obstetrics and gynaecology in our country.

\section{Methodology}

The research is built on a qualitative research design. We established two partial objectives. Firstly, to examine which core social competencies are important for doctors and which best practices are important for women and to compare the outcomes. Secondly, to identify core social competencies as a basic assumption for effective relationship between the doctors and the women.

The following research questions were asked within the research:

1. Research question: What characterizes a "good doctor"?

1a: What do doctor themselves consider to be important social competences for doctors?

$1 \mathrm{~b}$ : What best practices do women/expectant mothers expect?

2. Research question: What is the perceived level of social competence?

2a: How do doctors perceive the level of social competence?

2b: How do women/expectant mothers perceive the level of social competence?

3. Research question: What is the perceived level of education in this area?

3a: How do doctors perceive the level of undergraduate and postgraduate education?

3b: How do women/expectant mothers perceive the level of undergraduate and postgraduate education?

Two research methods were applied within the qualitative research: Three focus groups for doctors from different level of their experience and nine in-depth interviews with mothers from different experience with the parturition. The results of this research were then processed by qualitative analysis. 
The first phase, which took place in September 2018, focused on an investigation among doctors. During this phase of the research, a hospital-maternity hospital was selected, and within it respondents from the ranks of doctors and nurses were recruited. The research sample consisted of a closed group of interviewed persons in a specifically defined context. It was, therefore, a representative (typical) case. In the environment of a maternity hospital in Prague, we first investigated how doctors respond to certain questions - how they perceive the personal and social competences of a doctor/obstetrician from their point of view (how they perceive, experience them). The aim was to determine which competencies they considered important and which less so, how they perceived their level of development of these competences and how they evaluated the level of education in this area. In September 2018, there were three focus groups of six participants according to their length of hospital practice. The doctors were divided into residents, attending and consultants. Other questions included the doctors' sex and length of practice.

The focus groups lasted 1.5 hours and were moderated by the author. The informants wrote their opinions on moderation notes, then there was a discussion, and subsequently the notes were stuck onto a flipchart. One group sat in on an audio recording, the other groups rejected it.

The second stage - in-depth interviews with women/expectant mothers - took place between January and June 2019. During this stage, participants were selected based on their prenatal, perinatal and postnatal experience. The women were approached who were within six weeks of delivery to ensure approximately the same level of experience. The women were also asked their age, education, field, address, and number of pregnancies and births. The women were between 25 and 37 years old, and high school and university educated. As the participants spoke very openly in the interviews, an important ethical issue was to maintain their anonymity. The main concern of the medical participants was the possible misuse of their data by colleagues and superiors as well as by the general public.

The obtained data were rewritten and processed by the method of open coding and card lay-out techniques. In this way, several categories and subcategories were created. The coding was performed manually. Answers to research questions 2 and 3 were recorded on a 10-degree scale and subsequently supplemented by opinions and experiences that were also coded. The women in the group of women/expectant mothers were unable to assess the level of education of the doctors, but rather assumed it from the transferred experience; therefore, the scale was not completed. The data from the doctors and women/expectant mothers was then compared and a model of doctor competences was created. 


\section{Results}

The results are presented according to the research questions. In the first phase, aimed at identifying the attitudes of doctors, the question "What characterizes a good doctor?" was asked. At first, the terms competence and social competence were clarified. Each focus group developed a model of doctor competence. The doctors mentioned both skills and qualities. The following occupied a prominent place in all groups: 1. Professional knowledge and skills, 2. Communicative skills, 3. Skills to teach oneself and others, 4. Self-reflection - the ability to know your limits, 5. Balance and separation of work and private life. Other skills, Patient cooperation and Teamwork, only occurred in the group of consultants and attending doctors, and Holistic view in the attending doctor group. In the case of the consultants, the ability to teach was focused only on themselves, not on others, which, on the other hand, was emphasized by the residents.

The model of competency developed as a result of this phase of the investigation is compared with foreign models in Table 1:

\section{Table 1 Comparison of models of competency}

\begin{tabular}{|c|c|c|c|}
\hline $\begin{array}{l}\text { Accreditation Council } \\
\text { for Graduate Medical } \\
\text { Education, ACGME, } \\
\text { USA }\end{array}$ & $\begin{array}{l}\text { CanMEDS } 2005 \\
\text { Physician Competency } \\
\text { Framework, } \\
\text { Canada }\end{array}$ & $\begin{array}{l}\text { General Medical } \\
\text { Council, Good Medical } \\
\text { Practice, GMC (2007) }\end{array}$ & Model of Competency, 2019 \\
\hline Medical knowledge & Medical expert & $\begin{array}{l}\text { Knowledge, skills and } \\
\text { performance }\end{array}$ & $\begin{array}{l}\text { Expertise (abilities, } \\
\text { knowledge, skills) }\end{array}$ \\
\hline Professionalism & Professional & Professionalism & Holistic approach \\
\hline Patient care & Health advocate & $\begin{array}{l}\text { Relationships with } \\
\text { patients }\end{array}$ & Patient care \\
\hline $\begin{array}{l}\text { Interpersonal and } \\
\text { communication skills }\end{array}$ & Communicator & $\begin{array}{l}\text { Interpersonal and } \\
\text { communication skills }\end{array}$ & Communication skills \\
\hline $\begin{array}{l}\text { Practice-based } \\
\text { learning and } \\
\text { improvement }\end{array}$ & Scholar & Teaching & Teaching yourself and others \\
\hline & $\begin{array}{l}\text { Collaborator } \\
\text { Leader }\end{array}$ & $\begin{array}{l}\text { Communication, } \\
\text { partnership and } \\
\text { teamwork } \\
\text { Management and self- } \\
\text { management }\end{array}$ & $\begin{array}{l}\text { Self-management and } \\
\text { stress-management }\end{array}$ \\
\hline
\end{tabular}




\begin{tabular}{|l|l|l|l|}
$\begin{array}{l}\text { Systems-based } \\
\text { practice }\end{array}$ & Safety and quality & \\
\hline
\end{tabular}

Source: the author

The group of residents was dominated by Expertise, which, with Doctor acquiring experience, fell to third place, with Doctor's well-being and Communication coming to the forefront. Among the important personality traits doctors included: 1. Decisiveness, 2. Empathy, 3. Responsibility (moral responsibility), 4. Credibility (reliability). The most personal qualities were emphasized by residents, both in relation to work (diligence, reliability, initiative), and in relation to people (patience, decency, humility).

Overall, the doctors consider socially competent behaviour to be important and useful, especially to achieve better patient cooperation and compliance, conflict prevention and easier reaching of an agreement. They also see meaning in the feeling of well-done work and professional and personal growth. According to the doctors, patients would benefit by being more satisfied, feeling safer, having less fear and uncertainty, and at the same time having greater confidence in the doctor. Doctors mentioned that their responsibilities and compliance could be increased, whereby making the diagnosis and treatment more likely to succeed. For hospitals, the use of social competences would be important for gaining a better reputation and popularity, preventing conflicts and lawsuits and ultimately providing economic benefits.

However, doctors also mentioned the risks and reasons why the psychosocial approach cannot always be applied. Most of them were of the opinion that it is more personal and time consuming. They see the greatest risks in increasing psychological and emotional stress and in easier and faster burn-out. Another risk is increasing the time with the patient and breaching the professional distance, as well as fear of an increase in ethical conflicts. They see a disadvantage for the patient in longer waiting times, and higher costs. They also believe that some patients do not want or are unable to make choices, do not want to take responsibility, and are not interested in making decisions. It is less economically effective for hospitals to apply social competences (the doctor does less per time unit), it means increasing staffing costs: educating doctors, working with doctors - evaluation, control, staff evaluation, working with burnout (time and psychological burden on staff). Hospitals have limited capacity in terms of space and operation.

During the interviews, doctors also mentioned that the most common barriers result from the personality of the doctor, from his or her lack of psychological education, lack of time and a large volume of work. Patients are most often limited by the patient's personality, inability and unwillingness to take responsibility, unwillingness to share and negotiate, mistrust of the healthcare system and the doctor, and a lack of objective insight. On the part of the hospital, the 
barriers are time, money, space, doctors' workload, incompetent management, and insufficient support of the health insurance system.

Expectant mothers mentioned both the character of the doctor and his or her skills, motives and attitudes. Table 2 was create based on the respondents' answers, and includes the four components of social competency.

Table 2 Expectations of women/expectant mothers in terms of competency

\begin{tabular}{|c|c|c|c|c|}
\hline & $\begin{array}{l}\text { Interpersonal } \\
\text { Competence }\end{array}$ & $\begin{array}{l}\text { Interpersonal } \\
\text { competence }\end{array}$ & $\begin{array}{l}\text { Emotional } \\
\text { competence }\end{array}$ & $\begin{array}{l}\text { Communication } \\
\text { competence }\end{array}$ \\
\hline Character & $\begin{array}{l}\text { Likeable } \\
\text { Nice } \\
\text { Polite } \\
\text { Kind } \\
\text { Pleasant } \\
\text { Careful } \\
\text { Purposeful }\end{array}$ & $\begin{array}{l}\text { Humane } \\
\text { Willing/helpful }\end{array}$ & $\begin{array}{l}\text { Empathy } \\
\text { Sensitivity } \\
\text { Gentleness } \\
\text { Perceptiveness }\end{array}$ & \\
\hline Skills & $\begin{array}{l}\text { Maintains eye } \\
\text { contact } \\
\text { Smiles } \\
\text { Has a calm voice } \\
\text { Establishes } \\
\text { contact }\end{array}$ & $\begin{array}{l}\text { Shows interest } \\
\text { Has an individual } \\
\text { approach } \\
\text { Takes things } \\
\text { seriously } \\
\text { Is fully dedicated } \\
\text { Imparts the } \\
\text { feeling l'm not } \\
\text { bothering him or } \\
\text { her } \\
\text { Has sufficient } \\
\text { time } \\
\text { Partner approach } \\
\text { Equal access } \\
\text { Respect } \\
\text { Deference } \\
\text { Knows how to } \\
\text { calm people } \\
\text { down, give hope } \\
\text { Looks for } \\
\text { possibilities, }\end{array}$ & $\begin{array}{l}\text { Knows how to } \\
\text { empathize } \\
\text { Understands } \\
\text { Shows } \\
\text { compassion }\end{array}$ & $\begin{array}{l}\text { Knows how to explain } \\
\text { clearly and adequately } \\
\text { Checks their } \\
\text { understanding } \\
\text { Asks questions } \\
\text { Answers questions } \\
\text { Listens } \\
\text { Leads the discussion } \\
\text { Seeks solutions - } \\
\text { negotiates }\end{array}$ \\
\hline
\end{tabular}




\begin{tabular}{|l|l|l|l|l|}
\hline & & $\begin{array}{l}\text { solutions, not } \\
\text { errors }\end{array}$ & & \\
\hline Attitudes, motives & Likes their work & Likes people & & \\
\hline
\end{tabular}

Source: author

For women/expectant mothers, the doctor's behaviour is as important as his or her expertise. However, it was determined that where there is no competition, i.e. in the case of highly specialized and highly proficient doctors, inappropriate approaches would be tolerated by the participants. The participants are sure that if the doctor was more socially competent, prevention would generally improve and complications would be reduced, whereby reducing treatment costs and time. Patient compliance would also improve as a result of an increase in confidence. Patients would be more satisfied and would not seek help from alternative competitors. Better information from the doctor would reduce the search for information on social networks and, therefore, avoid misinformation. The participants are also sure that this would improve the overall picture of health care.

Unlike doctors, the participants do not see any risks if the level of social competence of the doctor is improved. One thing they may be worried about was that patients may misuse medical care and waiting times may become longer.

In the interviews, the participants consider the overwork and fatigue of doctors to be the most common barriers, their low motivation due to poor pay conditions and also the outdated education system. In the case of the patients, the participants see barriers in the passive attitude and obedience of some patients as well as fear and respect that will not allow them to be equal partners, even though this aspect was only mentioned by the participants in the case of the older generation of patients.

The second research question focused on assessing the level of development of social competences. Again, it was examined from both points of view, the doctor and the women/expectant mothers. The perceived level of social competences in both groups, doctors and women/expectant mothers is relatively similar and is slightly above average (6.5 out of 10). The level of social skills was evaluated differently and significantly better by women wishing to give birth by caesarean section, probably because professional competences are more important to them than social competences. From the answers, it was apparent that neither doctors nor women/expectant mothers were satisfied with the current level and would like it to improve.

The third research question focused on assessing the level of education. Here mostly doctors responded, women/expectant mothers do not have experience with the nature of education, but still consider the education system to be outdated and insufficient education as one of the primary 
barriers to the social competence of doctors. The doctors assessed the level of current education on a scale of $1-10$ (10=best), and on what level it should ideally be. The satisfaction of doctors with the level of education is shown in Table 3.

Table 3 Overview of the satisfaction of doctors with the level of education

\begin{tabular}{|l|l|l|l|l|}
\hline & \multicolumn{2}{|c|}{ Undergraduate education } & \multicolumn{2}{c|}{ Postgraduate education } \\
\hline & Real & Ideal & Real & Ideal \\
\hline Resident & 3 & 7.7 & 2.3 & 7.4 \\
\hline Attending & 3.8 & 6.7 & 1.5 & 7.7 \\
\hline Consultant & 1.8 & 8.3 & 1.7 & 7.5 \\
\hline
\end{tabular}

Source: author

The interviews showed that the doctors are not satisfied with the level of either undergraduate or postgraduate education. They consider this education too theoretical and often optional, so that other clinical subjects take priority. The doctors also mentioned that at the time of their studies they were overwhelmed with information from other subjects and that is why the subject of psychology or communication did not have much weight for them. Moreover, they did not come into contact with patients and when they were in higher years they concentrated on professional knowledge and skills. The interviews also showed that the level of education is slightly improving, but doctors themselves would appreciate change mainly in the form of teaching. According to the doctors, there is no system in postgraduate education, it is always up to the doctors themselves to choose. Therefore, young doctors often choose courses required for attestation, i.e. vocational training, there is no time or money for any others.

\section{Discussion}

The following section summarizes how the individual objectives have been achieved and the research questions answered. The survey empirically confirmed that both doctors and women/expectant mothers perceive the importance of the doctor's social competencies and the need for change.

The main objective was to form the characteristics of a "good doctor" from the point of view of the doctors themselves and from the women/expectant mothers. For both groups, social competencies and professional competencies were at the forefront, which were considered ideally balanced by both groups. Both groups considered communication competence (the art of explaining, asking, discussing, listening), interpersonal competence (patient-centred approach, collaboration and shared decision-making and partnering), emotional competence (empathy, 
emotional management) self and others) and intrapersonal competence (self-control, positive impression, good mood, stress management) to be among the social competences.

The result of the survey was a competency model that fully coincides with the British model. This finding shows that the needs and expectations of both patients and doctors are approximately the same throughout the world.

The empirical data obtained from the doctors in their answers to the second research question, i.e. how they perceive the level of development of social competences, show that doctors are aware of the importance of a psychosocial approach to patients and that they are not satisfied with the level of development of their social competences. They often feel helpless about how to provide this approach, they lack a sufficient psychological education in this area, as well as sufficient time and support. They also feel that not all patients are prepared to take responsibility and become an active participant in the treatment process. Even in the case of the expectant mothers, satisfaction with the approach was rather average; they see the reasons both in the personality of the doctor and his or her motivation, and in the lack of time and the poor education system.

The third research question concerned the level of medical education. Here, doctors agreed that the level of education is very low, both at the undergraduate and postgraduate level. This is also reflected in the overview of education at medical faculties prepared by J. Vecánová (2019). From the doctors' point of view, it is necessary to focus more on the practical application of psychological knowledge in everyday medical practice. Doctors would appreciate less theory and more practice. Subjects for training practical skills are optional and students prefer to choose clinical subjects that are more important and safer for them. It would also be advisable to increase the credibility of the subjects, to end with an examination so that students perceive the significance and importance of these subjects. In the current system, doctors do not perceive the priority of social competences at the educational level or at the hospital organization level. Socalled standardized patients have begun to be used in education abroad, but recently also in our country, whereby doctors try to communicate with professional actors who have precise instruction on how to proceed, so that the students can try different situations. The experience is particularly important for doctors to understand the role of the patient and, thereby, strengthen their empathy. It is also suitable to equip classrooms with audio-visual technology, to have the possibility to record simulations of specific clinical interviews, which of course brings additional financial costs. Last but not least, medical faculties need to create an environment for openness, cooperation, partnership, positivity (the openness and spontaneity of doctors is often blocked by fear of making mistakes, misuse of information against them, which was shown through some of 
the doctors' concerns during our survey). Doctors also consider postgraduate education as being very important. Although they admit that there are communication courses at the Institute of Postgraduate Medical Education, they do not attend them very often. This is usually due to a lack of time and because of priorities, which are increasingly built on vocational training, and it is often also a matter of finances. In this case, doctors would appreciate the possibility of education in hospitals where a person could be in the role of a "trainer" to help them deal with specific challenging communication and interaction situations. They would appreciate the opportunity to test model situations based on their own case reports. They also often emphasized the role of a mentor (a more experienced colleague), who would become a role model not only in solving professional problems but also in communicating and dealing with the patient. Despite the lack of time expressed by the doctors, they greatly appreciated the opportunity to stop by the focus groups and discuss social competences, whether they offered the chance to diversify or just to reflect, they agreed that such meetings were lacking.

This empirical survey is only the first stage, and will be followed by a more in-depth analysis of individual testimonies, which will lead to more precise views of doctors and nurses, which may contribute to a better understanding of mutual expectations. The next phase will focus on the points of view of doctors, how they perceive specific skills, how they use them, and to what effect, what they experience, and how the same situation is perceived and experienced by women/expectant mothers.

The limits of this work certainly include the small sample of respondents; however, this work does not require generalization, but it is rather an attempt to look deeper into the nature of the phenomena being observed. The choice of sample, both in the case of the women/expectant mothers and the doctors was targeted and it should be noted that the results, especially in the case of the doctors, can be influenced by the fact that not only those who had the time, but also those who were willing to be involved were chosen for the focus groups.

It would also be advisable to extend the sample to all medical specialties or at least those where a relationship and communication between the doctor and the patient is assumed.

\section{Conclusion}

The main aim of this paper was to try to answer what the best practices of the doctor/obstetrician are. Based on the answers from the point of view of the doctor/obstetrician and from the point of view of women/expectant mothers, prepare for discussion and verification of the model of social competences of the doctor/obstetrician and propose partial steps for more effective education of doctors. On the basis of the focus groups with the doctors, their attitudes and opinions were 
mapped and, based on in-depth interviews with the expectant mothers, their needs and expectations in relation to doctors were mapped.

The research showed that the social competences of doctors are important not only for women/expectant mothers but also for doctors, and that both groups consider it necessary to develop them both at the level of undergraduate and postgraduate education. The most important social competences for both groups are communication competencies, interpersonal competencies, intrapersonal competencies and emotional competencies.

The doctors confirmed that they perceive education in the framework of social competences as insufficient, either because it is too theoretical or because it is not regarded as being so important by students. This situation is similar in terms of postgraduate education, where doctors feel that education and development in social competences does not have the same priority and support as education and development in professional competences.

The benefit of this empirical study is to perceive not only the patient's perspective, needs and expectations, but also the perception, opinions and needs of the doctor, because only in this way can we achieve the desired result and that is mutually satisfactory. The outcome is the still perceived need for a change in the curriculum within the undergraduate and postgraduate education of doctors and a greater emphasis on the development of social competences, both at the level of education and at the level of the cultures of hospitals and healthcare facilities. Medical care is not only about diagnosis and treatment, but a holistic approach should be emphasized.

In conclusion, the competency model of doctors has several practical implications. The results could be used as a measure to determine content for assessments of competency. Hospital administrators can adopt rapid adjustment measures to ensure clinical practice in accordance with the development of a virtuous cycle. The results can serve as an important theoretical basis for health administrative departments, to promote reform of the methods and content of clinical training. Furthermore, the competency model can provide an important reference basis for constructing doctor competencies with different specialties or clinical settings. In educational settings, the tool could be used by students to self-evaluate their skill level both before and after learning activities. This feedback may help faculty members determine how their students perform. 


\section{References}

ACGME Outcome Project. (2001) Accreditation Council for Graduate Medical Education Web site. Available at: http://www.acgme.org. 2000. Accessed October 1.

Appleby L. Suicide during pregnancy and in the first postnatal year. BMJ. 1991;302(6769):137-40. https://doi.org/10.1136/bmj.302.6769.137

Balint, E. (1969). The possibilities of patient-centred medicine. N. Mead, P. Bower / Social Science \& Medicine 51 (2000) 1087士11101107. https://doi.org/10.1016/S0277-9536(00)00098-8

Bailham \& Joseph. (2003). In: Takacs, L., Seidlerová, J.,(2013) Psychosociální klima porodnice očima rodiček I. Výsledky celorepublikového průzkumu spokojenosti s perinatální péčí v ČR u reprezentativního souboru 1195 rodiček. Česká gynekologie., 78, 2

Bourne S, Lewis E. (1992). Psychological aspects of stillbirth and neonatal death. An annotated bibliography. London: Tavistock Clinic.

Byrne, P., \& Long, B. (1976). Doctors Talking to Patients.London: HMSO.

Cain AC, Cain BS. (1964). On replacing a child. J Am Acad Child Psychiatry. 5:445-56. https://doi.org/10.1016/S0002-7138(09)60158-8

Condon J. (2010). Women's mental health: a "wish-list" for the DSM V. Arch Womens Ment Health. 13(1):5-10). https://doi.org/10.1007/s00737-009-0114-1

Coulter A, Ellins J. (2006). Patient focused interventions: a review of the evidence. London: The Health Foundation.

Coulter, A. and Magee, H. (2003). The European patient of the future-state of health. Open University Press, Maidenhead.

DiMatteo et al. (1996). In: Takacs, L., Seidlerová, J.,(2013) Psychosociální klima porodnice očima rodiček I. Výsledky celorepublikového průzkumu spokojenosti s perinatální péčí v ČR u reprezentativního souboru 1195 rodiček. Česká gynekologie., 78, 2

Dodge, K. A. (1985). Facets of social interaction and the assessment of social competence in children. In B. Schneider, K. H. Rubin, \& J. Ledingham (Eds.), Children's peer relations: Issues in assessment and intervention (pp. 3-22). New York: Springer-Verlag. https://doi.org/10.1007/978-1-4684-6325-5_1

Eklun, J.H., Holmstrom, I.K., Kumlin, T. et al. (2017). Patient Education and Couseling 102, 3-11, pp. 6-8

Epstein, RM. \& Hundert, EM. (2002). Defining and assessing professional competence. JAMA. Jan 9;287(2):226-35. https://doi.org/10.1001/jama.287.2.226

Frank J. R.. The CanMEDS 2005 physician competency framework. Ottawa: the Royal College of Physicians and Surgeons of Canada. 
Good Medical Practise. (2013). General Medical Council Web site. Available at: http:// www.gmcuk.org/guidance. Accessed March 25.

Gordon, T., Edwards, S. (1995). Making the patient your partner. 1st.edition, pages 213. Auburn House, Westport, Connecticut, London.

Green M, Solnit AJ. (1964). Reactions to the threatened loss of a child: a vulnerable child syndrome pediatric management of the dying child, Part III. Pediatrics. 1964;34(1):58-66.

Grol, R., de Maeseneer, J., Whitefield, et al. (1990). Disease-centred versus patient-centred attitudes: comparison of general practitioners in Belgium, Britain and the Netherlands. Family Practice,7(2), $100 \pm 104$. https://doi.org/10.1093/fampra/7.2.100

Hall, W., et al. (1999). 'Assessment of physician performance in Alberta: the Physician Achievement Review'. Canadian Medical Association Journal, 161: 52-57.

Hasman A, Hope T et al. (2006). Health care need: three interpretations. J Appl Philos. 23:145e56. https://doi.org/10.1111/j.1468-5930.2006.00325.x

Hundert, E.M., F. Hafferty, and D. Christakis. (1996). Characteristics of the informal curriculum and trainees ethical choices. Academic Medicine 71 (6):624-42. https://doi.org/10.1097/00001888-19960600000014

Irvine D. (2001). Doctors in the UK: their new professionalism and its regulatory framework. Lancet. 358(9295):1807-10. pmid:11734261. https://doi.org/10.1016/S0140-6736(01)06800-3

Kelly-Thomas, K. (1998). Clinical and Nursing Staff Development . Philadelphia, PA: Lippincott.

Klaus M, Kennel J. (1982). Parent-infant bonding. St Louis: C. V. Mosby.

Laine, C., \& Davidoff, F. (1996). Patient-centered medicine: a professional evolution. Journal of the American MedicalAssociation,275, 152+156. https://doi.org/10.1001/jama.1996.03530260066035

Lewis E, Page A. (1978). Failure to mourn a stillbirth: an overlooked catastrophe. Br J Med Psychol. 1978;51(3):237-41. https://doi.org/10.1111/j.2044-8341.1978.tb02468.x

Lipkin, M., Quill, T., \& Napodano, R. (1984). The medical interview: a core curriculum for residencies in internal medicine. Annals of Internal Medicine,100, 277 \pm 284 . https://doi.org/10.7326/0003-4819-100-2277

Little P., Everitt H., Williamson I. et al. (2001). Preferences of patients for patient centred approach to consultation in primary care: observational study . British Medical Journal. 322 : $1-7$. https://doi.org/10.1136/bmj.322.7284.468

Maudsley, R., Wilson, D., Neufield, V. et al. (2000). 'Educating future physicians for Ontario: phase II'. Academic Medicine, 75: 113-126. https://doi.org/10.1097/00001888-200002000-00005 
McWhinney, I. (1989). The need for a transformed clinical method. In M. Stewart, \& D. Roter, Communicating with medical patients. London: Sage.

Mead, N., Bower, P. (2000). Measuring patient-centredness: a comparison of three observation-based instruments, Patient Education and Counseling, 39, 71 \pm 80 . https://doi.org/10.1016/S0738-3991(99)000920

Michels, Kruske, \& Thompson (2013). In: Takacs,L., Seidlerová, J.,(2013) Psychosociální klima porodnice očima rodiček I. Výsledky celorepublikového průzkumu spokojenosti s perinatální péčí v ČR u reprezentativního souboru 1195 rodiček. Česká gynekologie., 78, 2.

Palmer KT, Harling CC, Harrison J. (2002). Good medical practice: guidance for occupational physicians. Occupational medicine (Oxford, England). Sep;52(6):341-52.

https://doi.org/10.1093/occmed/52.6.341

Posnaski EO. (1972). The "replacement child": a saga of parental unresolved grief. J Pediatr. $81: 1160-5$.

Smékal, V. (2007). Pozvání do psychologie osobnosti. 2. vyd. Brno: Barrister and Principal, p. 523.

Stewart MA , Brown JB , Weston WW et al. (2003). Patient Centred Medicine: Transforming the Clinical Method, 2nd edn . Oxford : Radcliffe Medical Press.

Stewart, M., Brown, J., Weston, W. et al. (1995a). Patient-centered medicine: transforming the clinical method. London: Sage.

Swing SR. (2007). The ACGME outcome project: retrospective and prospective. Med Teach. Sep;29(7):648-54. pmid:18236251. https://doi.org/10.1080/01421590701392903

Takacs,L., Sobotková, D., Šulová, L.(2015). Psychologie v perinatální péči. Praha: Grada Publishing.

Takacs,L., Seidlerová, J. (2012). Psychosociální aspekty v současném českém porodnictví. Praha: FFUK.

Takacs,L., Seidlerová, J. (2013). Psychosociální klima porodnice očima rodiček I. Výsledky celorepublikového průzkumu spokojenosti s perinatální péčí v ČR u reprezentativního souboru 1195 rodiček. Česká gynekologie, 78, 2.

Takacs,L., Seidlerová, J. (2013). Psychosociální klima porodnice očima rodiček II. Prediktory spokojenosti s perinatální péčí v České republice. Česká gynekologie. 78, 3, pp. 269-275.

Vecánová, J. (2019). Psychologické aspekty komunikace mezi lékařem a pacientem v kontextu poskytované péče. (Diplomová práce). Praha: FFUK.

Veteška, J., Tureckiová, M. (2008). Kompetence ve vzdělávání. Praha: Grada. Pedagogika (Grada). 
Violato et. al. (1997). 'Using peers, self, patients and co-workers to assess physician performance'. Academic Medicine, 72: 582-584. https://doi.org/10.1097/00001888-199710001-00028

Winefield, H., Murrell, T., Clifford, J. et al. (1996).The search for reliable and valid measures of patientcentredness. Psychology and Health. 11, 811 \pm 824 . https://doi.org/10.1080/08870449608400277 